\title{
EARLY DIAGNOSIS OF METABOLIC DISEASES OF THE SKELETON IN DAIRY COWS
}

\author{
J. DOUBEK, P. JAGOS and J. TOTH
}

\begin{abstract}
Department of Diagnosis, Therapy and Control of Animal Diseases, University of Veterinary Science, 61242 Brno
\end{abstract}

Received November 10, 1987

\author{
$A b \leq t r a c t$
}

D o u b e k J., P. J a g $\circ$ s, J. $T \circ t$ h: Early Diagnosis of Metabolic Diseases of the Skeleton in Dairy Cows. Acta vet. Brno, 58, 1989: 31-51.

In order to improve the system of preventive diagnosis of osteopathies in cattle a complex examination of health condition of 195 cows from 16 large-capacity farms and of 37 clinical patients was carried out during the winter season. Diagnostical validity of selected clinico-biochemical parameters in various forms of metabolic diseases of the cattle skeleton was assessed.

The results of this examination show that the determination of $\mathrm{Ca}$ and inorganic $\mathrm{P}$ concentrations in the blood plasma and urine is of no significance for an early diagnosis of metabolic diseases of cattle skeleton, i.e. in the latent or prodromal stages of the disease. Data obtained by chemical analysis of the tuber coxae biopsy samples taken from cows with various forms of osteopathies due to nutritional deficiencies showed characteristic differences when compared with the controls and were found to be pathognomonic for the processes going on in a skeleton. This finding was verified by histological examination of bioptic osteosamples.

Evaluation of the results of $t$. coxae spongiosa chemical analysis proved the usefulness of the ash weight determination in $1 \mathrm{~g}$ of fat-free dry matter, of the ash weight in $1 \mathrm{~cm}^{3}$ and of the $\mathrm{Ca} / \mathrm{P}$ index in the bone ash in the diagnosis of various forms of metabolic osteopathies in cows. Histological examination is not necessary from the viewpoint of an early diagnosis of metabolic osteopathies in cows but it may complement the diagnostic conclusion. It can be concluded that by determination of the ash content in $1 \mathrm{~g}$ of fat-free dry 
matter the skeletal malacic processes and by determination of the ash weight in $1 \mathrm{~cm}^{3}$ of spongy bone the porotic processes can be diagnosed already in the latent, or prodromal, phase of the disease. Determination of $\mathrm{Ca} / \mathrm{P}$ index in the bone ash can further specify the differential diagnosis.

Dairy cows, metabolic osteopathies, early diagnosis, bioptic osteosamples, bone ash, $\mathrm{Ca} / \mathrm{P}$.

The diagnosis of metabolic diseases in cattle. skeleton is very demanding. Great difficulties appear especially in the latent, or prodromal, phase of the disease when no symptoms of the skeleton affection are apparent. However, the disturbance of the health condition is expressed by the performance decrease ( $\mathrm{P} i \mathrm{~b} \circ \mathrm{t} \mathrm{h}$ 1976). Also the blood plasma (serum) analysis - Ca, inorganic $P$, total catalytic activity of alkaline phosphatase - and the urine analysis - $\mathrm{Ca}$, inorganic $\mathrm{P}$ ( $\mathrm{J}$ a $\mathrm{g} \circ$ s et al. $1975 \mathrm{~b})$ show often to be insufficient. Therefore, the chemical and histological examination of bioptic osteomaterial, enabling the determination of metabolic disturbances in osteotrophic materials already in the latent phase, gains significance in the preventive diagnosis of osteopathia in cattle managed under industrial conditions. The disturbances in osteotrophic elements metabolism are marked by characteristic physico-chemical and morphological changes in bone substance ( $P$ $i$ b 0 t $h$ 1967). Pri b t h (1966), Pri both and Fritzsche (1969) and others showed, on the basis of a comparative analysis, that the tuber coxae spongy bone appeared to be the most reliable indicator of changes in the chemical composition taking place in a skeleton.

The lowerea degree of skeleton mineralization, characteristic for rachitis and osteomalacia, can be proved by the ash weight determination and its expression per weight unit of fat-free dry matter (FFDM). For the differential diagnosis of metabolic osteopathies in cattle the ash weight per volume unit of $t$. coxae spongy bone also represents an important criterion, the reason being that skeleton metabolic disturbances are of ten characterized not only by inorganic but also by organic changes in the bone tissue proportion which is characteristic for osteoporosis (P r i b o t h 1976, 1978).

With regard to etiopathogenesis of skeleton diseases the diagnostical value of the ash weight expressed per FFDM weight unit and per volume unit of $t$. coxae spongy bone is considered to be of limited importance ( $\mathrm{J}$ a $\mathrm{g} \circ \mathrm{s}$ et al. 1975b, 1978; $\mathrm{P} \mathrm{r}$ i b o t h 1976, 1978). L e g e 1 (1972/1973) and $J$ a $g \circ \breve{s}$ et al. (1975b, 1976) demonstrated characteristic changes in values of the $\mathrm{Ca} / \mathrm{P}$ parameter in the bone tissue of various cattle categories in dependence on the mineral nutrition plane.

For a more precise diagnosis of osteopathies in cattle $\mathrm{S}$ e $\mathrm{f} f \mathrm{n}$ e $\mathrm{r}$ and $P$ r i b o t h (1969) recommend to combine the chemical analysis of bioptic osteosamples with their histological examination.

The aim of the presented work was to evaluate the significance of selected clinico-biochemical parameters from the viewpoint of an early diagnosis of metabolic diseases in cattle skeleton.

\section{Materials and Methods}

Clinico-laboratory examination was carried out on cows $(n=232)$ coming from 16 herds in a beet-growing area and on cows hospitalized in the clinic of ruminants diseases of the Department of Diagnosis, Therapy and Control of Animal Diseases at the University of Veterinary Science in Brno. 
The animals were kept in areas with litter housing and the examination was carried out during winter feeding period (December - April). From every herd a group of $10-15$ clinically healthy cows, representatives of the herd, was examined. The group comprised animals 2 - 6 weeks post partum, 4 - 5 months pregnant and of dry cows.

In selected cows, breed, age, performance in the preceding lactation, actual yield (per preceding month), and actual herd performance were determined. Feed rations (silage quality, contents of starch units, digestible nitrogen substances, $\mathrm{Ca}$ and $\mathrm{P}$ ) were evaluated on the basis of feed analyses and performance. Health condition in herds for the preceding two years was assessed.

On the basis of health and performance analyses the herds were divided in groups or subgroups.

Group I ( $n=57)$ comprised of clinically healthy cows of Bohemian Pied breed, aged 3 - 10 years. The animals came from herds where nutrition showed no deficiencies in investigated parameters. Also in the feed technology no defects were found and during the preceding two years metabolic osteopathies were not observed. Milk yield of the preceding lactation of the examined cows ranged within 3800 and $4200 \mathrm{~kg}$, the actual yield remained approximately at the same level as in the same period of the last year. This group served as control.

Group II $(n=138)$ included clinically healthy cows of Bohemian Pied breed, aged 3 - 10 years. The animals originated from 11 herds where cases of generalized osteopathis occurred over the last two years. This disease contributed significantly to a total morbidity and emergency slaughter. Milk yield of the examined cows ranged within 2800 and $3500 \mathrm{~kg}$ of milk over the preceding lactation and varied greatly. Analyses of feed rations and technology revealed serious deficiencies in nutrition. These deficiencies were of a long-term character, i.e. unsuitable feed rations were fed at least two months prior to the examination. The selected herds were further divided into subgroups according to the found disbalances.

Subgroup II/1 $(n=29)$ included cowsfrom two herds where feed rations were deficient in $\mathrm{P}$ (ca $90 \%$ of the feeding standard). As for other parameters, the feed rations corresponded to the standard.

Subgroup II/2 ( $n=61)$ comprised of cows from 5 herds in which the feed rations were characterized by $\mathrm{Ca}$ surplus (ca $250 \%$ of the requirement) and by $P$ deficiency (ca $85 \%$ of the requirement).

Subgroup II/3 ( $n=15)$ included animals from one herd in which nutrition was found to be deficient as for as standard requirements are concerned: $\mathrm{Ca}(\mathrm{ca} 80 \%), \mathrm{P}(\mathrm{ca} 90 \%)$, starch units (ca $90 \%)$ and digestible nitrogen substances (ca $80 \%$ ).

Subgroup II/4 $(n=33)$ included cows from three herds. Feed rations had high actual and potential acidity (silage with high content of lactic and acetic acids, broader nutrient ratio), the content of investigated minerals being also not quite balanced.

Group III $(n=37)$. This group included cows of Bohemian Pied breed, occassionally of Black Pied breed, aged 3 - 14 years, in various stages of reproduction cycle. Clinical syndrome of skeleton affection was found in animals and they were hospitalized in the clinic or treated as out-patiens - subgroups II/2 - II/4. The duration of the manifest phase of the disease was different $(2-14$ days $)$. Deficiency in nutrition was of a longer character and according to its characteristics the cows were allocated into two subgroups.

Subgroup III/1 $(n=23)$ comprised of animals coming from farms where the feed rations were characterized by a broad $\mathrm{Ca} / \mathrm{P}$ ratio and a high actual and potential acidity. 


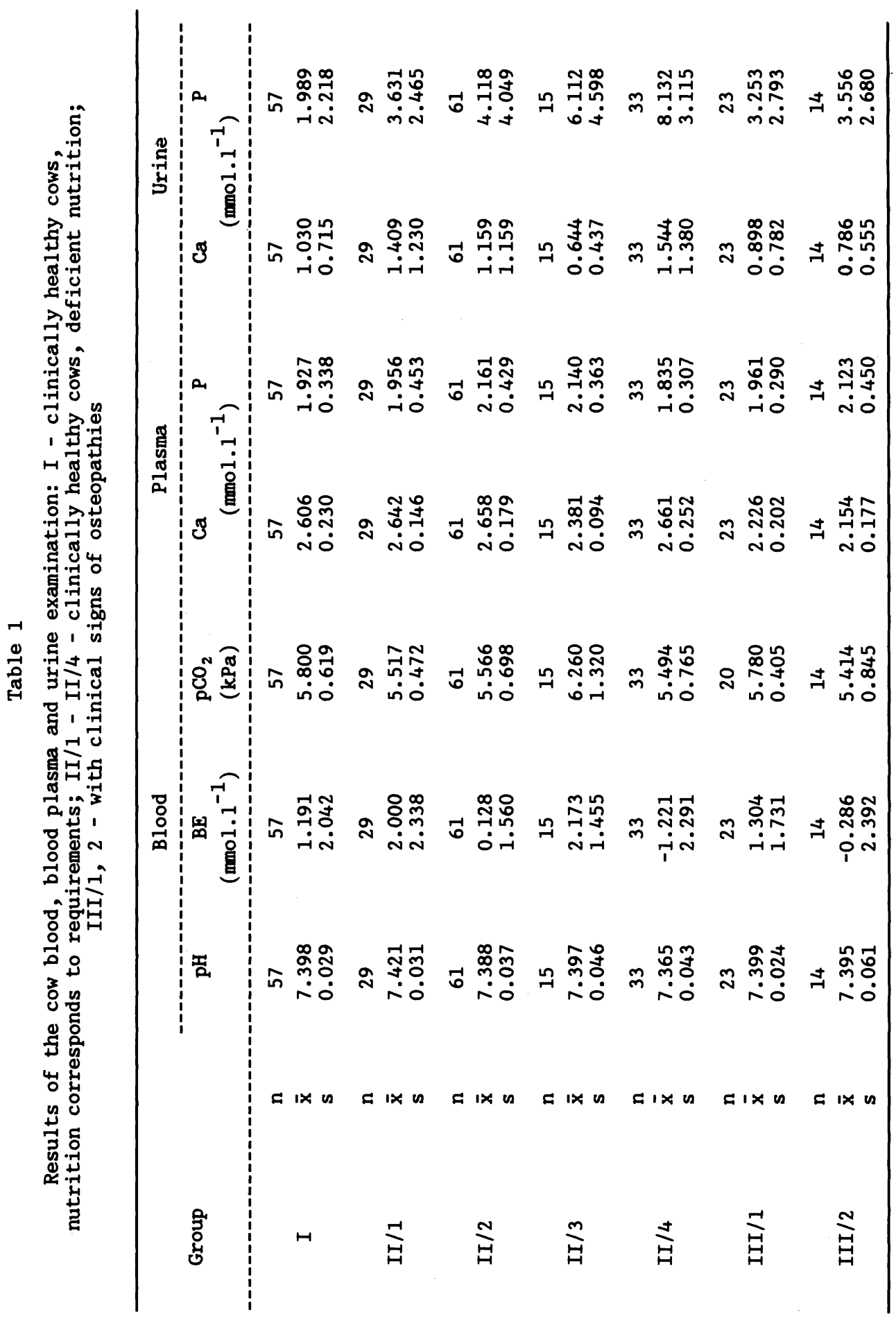


Subgroup III/2 $(n=14)$ consisted of cows, the feed rations of which were found to be deficient: Ca (ca $80 \%$ ), starch units (ca $90 \%$ ), digestible nitrogen substances (ca $80 \%$ ) and in several also P (ca $90 \%$ ) compared with the standard.

Screening of urine and milk samples was carried out in selected animals. After the tentative examination, samples of blood, blood plasma, urine, and bioptic osteosamples were analyzed in the laboratory. Parameters of the acid-base balance $\left(\mathrm{pH}\right.$, base excess, $\left.\mathrm{pCO}_{2}\right)$ in venous blood were determined using the Astrup equilibration method. Calcium and inorganic phosphorus concentrations were determined in blood plasma and urine, the method of atomic absorption spectrometry (AAS) being used for $\mathrm{Ca}$ determination while that of photometry was applied for determination of inorganic $P$ content. Bone tissue sample was obtained by the biopsy of tuber coxae using a special instrument. By analysis of the spongy bone $\left(\mathrm{V} \doteq 0.541 \mathrm{~cm}^{3}\right)$ a weight of fat-free dry matter, ash, $\mathrm{Ca}$ and $\mathrm{P}$ was obtained. Fat-free dry matter (FFDM) was obtained following the fat extraction by drying at $105^{\circ} \mathrm{C}$ to constant weight, ash by mineralization at $550^{\circ} \mathrm{C}$ for 48 hours. The ash weight was expressed per $1 \mathrm{~g}$ of fat-free dry matter and per $1 \mathrm{~cm}^{3}$ of spongy bone. The expression of FFDM weight per $1 \mathrm{~cm}^{3}$ was calculated from the ash values in $1 \mathrm{~g}$ of FFDM and in $1 \mathrm{~cm}^{3}$. The ash weight in $1 \mathrm{~g}$ of FFDM and specific gravity of FFDM were expressed in per cent of values of these parameters in healthy cattle. Calcium was determined by an AAS method and inorganic phosphorus photometrically using model solutions. Their ratio $(\mathrm{Ca} / \mathrm{P})$ was calculated from the found values.

The results of the biochemical examination were statistically evaluated.

Histological examination of biopsy samples was carried out in all animals of the group III (clinical syndrome - osteopathy) and in $50 \%$ of animals of the groups I and II. Bone material was fixed immediately after sampling in $10 \%$ formalin. The bone material was decalcificed in a usual way. The material was then embedded into paraffin and from the tissue blocks histological sections $(6 \mu \mathrm{m})$ were prepared, then stained by azan and hematoxylin-eosin and then microscopically examined.

\section{Results}

No symptoms of the disease were observed applying clinical examination methods in cows from the group I and II. In animals of the group III, a varying degree of apathy, good to less good nutritional condition, anorexia, slow-down of rumen motility; rigid posture and wood-biock gait, shifting from one leg to the other, difficult getting up, long kneeling on carpal joints, long to permanent (in some animals) recumbency.

The results of biochemical examination are presented in Tables 1 - 4 .

\section{Histological examination}

Histological examinations were kindly carried out at the Department of Anatomy, Histology and Embryology. For histological diagnosis of osteopathies the following structures 


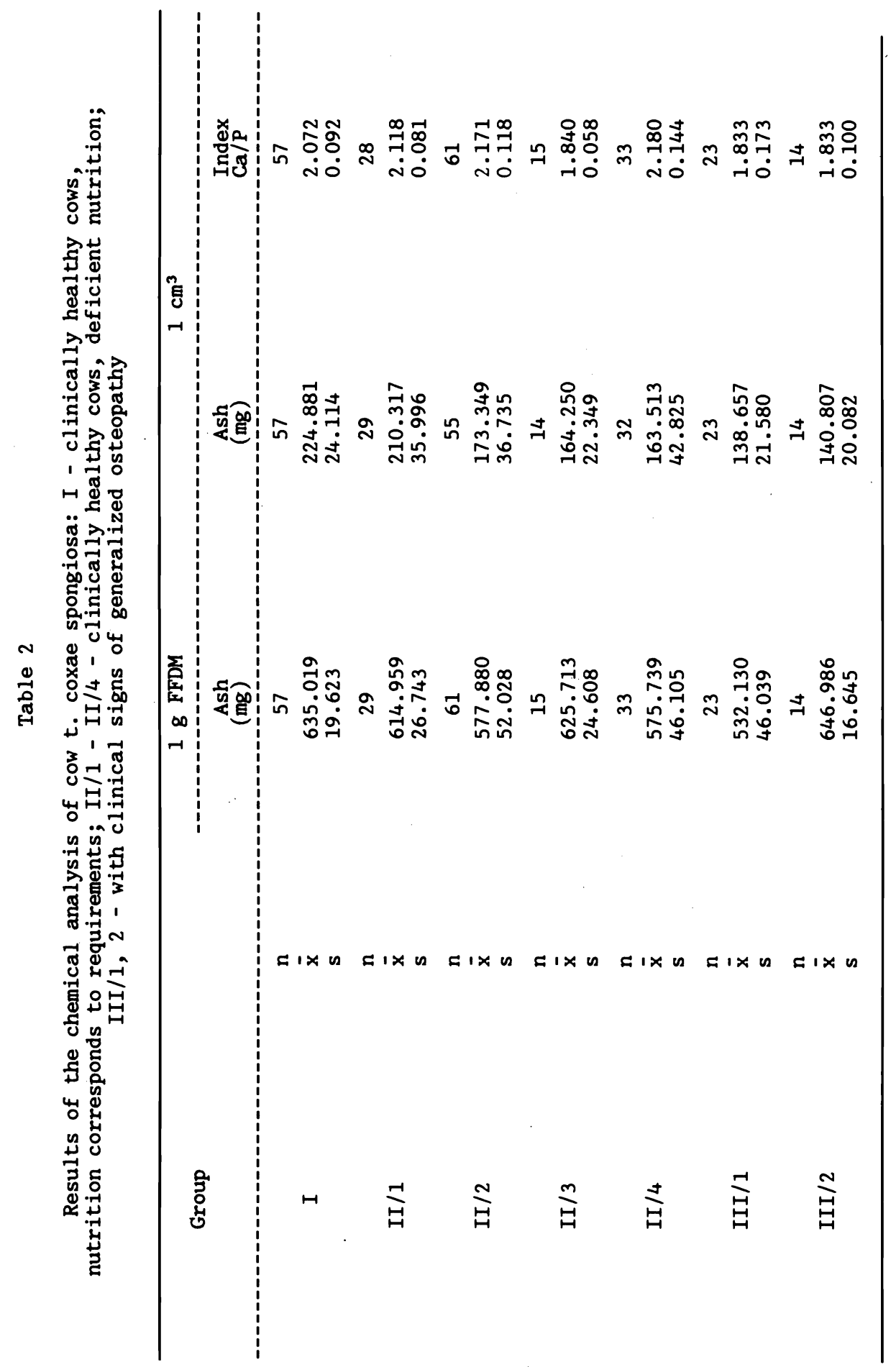


are important: growth cartilage (growth zone; in animals up to 5 - 6 years of age) and spongy bone of the iliac tubercle itself and of the ala ossis ilii.

In all histologically examined bioptic osteosamples of the group I cows the histological finding was normal and characterized by the following signs:

\section{Growth zone:}

On proximal border the presence of endochondral ossification centres, on distal border a continuous ossification zone (erosion line), simultaneously the formation of primary marrow cavities (chondrolytic activity), straight-oriented trabeculae, the resorption of oriented trabeculae and mineral deposition into the osteoid was also observed.

\section{Spongy bone:}

Ground substance of trabeculae mineralized and arranged into lamellar systems, lamellar systems separated from each other by layers of ground refractive bone substance, weak resorption of the primary spongy tissue and formation of small cavities, trabeculae stained regularly and composed of individual, with their surface in parallel coursing lamellae and bone cells.

In cows of the group II/1 following changes were found:

Growth zone:

Prolongation of the cartilage columns, straight-oriented trabeculae deformed, partial absence of primary spongy tissue, on metaphyseal margin irregular demarcation of the cartilage.

\section{Spongy bone:}

Osteoid borders on the surface of individual trabeculae (osteoid borders are characterized by a changed structure of ground substance with an absence of minerals), partially perilacunar osteoid areas (impaired mineralization also inside the trabeculae in the vicinity of cavities and bone tubules), clear lamellar structure in bone tubules sporadically. The changes were assessed as pathognomonic for osteomalacia. 
Table 3

Statistical evaluation of the results of $t$. coxae spongiosa chemical analysis in cows: I - clinically healthy cows, nutrition corresponds to requirements; II/1 - II/4 - clinically healthy cows, deficient nutrition; III/1, 2 - with clinical signs of osteopathies ( - insignificant, + significant, + highly significant)

\begin{tabular}{|c|c|c|c|c|c|c|}
\hline I & $I I / 1$ & $I I / 2$ & $\mathrm{II} / 3$ & $\mathrm{II} / 4$ & III/1 & III /2 \\
\hline Ash/g FFDM & ++ & + & - & - & ++ & + \\
\hline $\mathrm{Ash} / \mathrm{cm}^{3}$ & + & + & + & + & + & $+t$ \\
\hline $\mathrm{Ca} / \mathrm{P}$ & + & + & ++ & + & + & ++ \\
\hline
\end{tabular}

Table 4

Comparison of average values of ash $/ \mathrm{g}$ FFDM and FFDM $/ \mathrm{cm}^{3}$ expressed in per cent, cows: I - clinically healthy, nutrition corresponds to requirements; II/I - II/4 - clinically healthy, deficient nutrition; III/1, 2 - with clinical signs of osteopathies

\begin{tabular}{|c|c|c|c|c|}
\hline Group & $\begin{array}{l}\text { Characterization } \\
\text { of feed rations }\end{array}$ & $\begin{array}{l}\text { Clinical } \\
\text { condition }\end{array}$ & Ash/g FFDM & $\mathrm{FFDM} / \mathrm{cm}^{3}$ \\
\hline I & balanced & healthy & 100.00 & 100.00 \\
\hline $\mathrm{II} / 1$ & P deficiency & helthy & 96.84 & 96.57 \\
\hline$I I / 2$ & $\begin{array}{l}\mathrm{P} \text { deficiency, } \\
\mathrm{Ca} \text { excess }\end{array}$ & healthy & 91.00 & 84.71 \\
\hline $\mathrm{II} / 3$ & $\begin{array}{l}\text { deficiency } \\
\text { of } \mathrm{Ca}, \mathrm{P} \text { and } \\
\text { nutrients }\end{array}$ & healthy & 98.53 & 74.13 \\
\hline $\mathrm{II} / 4$ & $\begin{array}{l}\text { acidogenic, } \\
\text { broad nutrient } \\
\text { ratio }\end{array}$ & healthy & 90.66 & 80.20 \\
\hline III/1 & $\begin{array}{l}\text { acidogenic, } \\
\text { broad } \mathrm{Ca} / \mathrm{P} \\
\text { ratio }\end{array}$ & $\begin{array}{l}\text { symptoms } \\
\text { of skeleton } \\
\text { disease }\end{array}$ & 83.80 & 73.58 \\
\hline III $/ 2$ & $\begin{array}{l}\text { deficiency } \\
\text { of Ca, } P \text { and } \\
\text { nutrients }\end{array}$ & $\begin{array}{l}\text { symptoms } \\
\text { of skeleton } \\
\text { disease }\end{array}$ & 101.88 & 61.46 \\
\hline
\end{tabular}


In most of the histological preparations of the subgroup II/ 2 and II/ 4 cows these changes were observed:

\section{Growth zone:}

Prolongation of cartilage columns, straight-oriented trabeculae deformed, partial to complete absence of primary spongy tissue, on metaphyseal margin irregular demarcation of cartilage, presence of tongue-like projecting fragments of the cartilage into metaphyses.

\section{Spongy bone}

Presence of osteoid margins on the surface of individual trabeculae, partially perilacunar osteoid areas and clear lamellar structure in the bone tubules, trabeculae narrower and less frequent. Found changes were assessed as pathognomonic for malaco-porotic process.

The changes observed in cows of the subgroup III/1 were of the same character as those in the subgroups II/2 and II/4, being, however, more pronounced. Especially the osteoid margins were broader, the finding of perilacunar osteoid areas was regular as well as the clear lamellar structure in the bone tubules.

In animals of the subgroup II/3 and III/2 a qualitatively identical histological finding was demonstrated. The changes in the subgroup III/2 were assessed as more pronounced. Osteoporosis of bone substance (narrow trabeculae and a reduced number of them) was characteristic. The changes were assessed as pathognomonic for osteoporosis.

\section{Discussion}

Clinico-biochemical examination has shown that the response of the organism to mineral deficiency and to other factors in the feed ration varies greatly. Although the shortcomings in the nutrition of group II and III cows were relatively severe, they were not reflected in the indices obtained from blood plasma and urine.

Biochemical findings in blood plasma and urine (Tab. 1) were, with the exception of the subgroup II/4 ( $\mathrm{Ca}$ and inorg. $P$ concentration in urine) and the subgroup III/2 
(ca concentration in blood plasma), within the reference values ( $J$ a $g$ o š et al. 1975a, 1981a).

The values of ash found in the group I (Tab. 2) exceeded the values presented in literature as marginal values from the viewpoint of the difference in physiological and pathological course of osteogenesis. $\mathrm{P} \mathrm{r}$ i b o t h et al. (1972) and $\mathrm{P} r \mathrm{i} b \circ \mathrm{t} \mathrm{h}(1976,1978)$ have reported the ash value of $620 \mathrm{mg}$ and $616 \mathrm{mg} \cdot \mathrm{g}^{-1}$, resp., of FFDM of the $t$. coxae spongy bone and the ash value of $220 \mathrm{mg} \cdot \mathrm{cm}^{-3}$ of fresh spongy tissue as the lower limit for the assessment of skeleton of healthy dairy cows. ¿ e r n ý $(1977,1980)$ regards the ash value of $600 \mathrm{mg} \cdot \mathrm{g}^{-1}$ of FFDM, based on histological examination of $t$. coxae biopsy samples of dairy cows, as the value determining physiological level of skeleton mineralization. $J$ a $g$ o s et al. (1978) give the ash values of $620 \mathrm{mg} \cdot \mathrm{g}^{-1}$ of FFDM and $200 \mathrm{mg} \cdot \mathrm{cm}^{-3}$ of $\mathrm{t}$. coxae spongy matter as the critical limit for health and high milk yield.

Results of the ash determination in the group I are in accordance with the findings of similar examinations carried out by $\mathrm{P} r \mathrm{i} b$ o $\mathrm{h}$ et al. (1969), $\mathrm{S}$ e $\mathrm{f} f \mathrm{n}$ e $\mathrm{r}$ and P r i b o t h (1969), K o n i (1979), $\quad$ P r b o t h and $\mathrm{K} \circ \mathrm{n} \mathrm{i}$ (1980) and by us ( $\mathrm{J}$ a $\mathrm{g} \circ \breve{\mathrm{s}}$ et al. 1981b).

Also the morphological structures of bioptic osteosamples were classified as typical of a healthy animal.

From the highly significant decrease of the ash value in $1 \mathrm{~g}$ of FFDM (Tab. 2 and 3 ) of subgroup II/1 cows (clinically healthy cows, $P$ deficiency in feed rations) can be concluded that a disturbance in the ratio of bone mineral and organic matrix occurred on behalf of bone mineral. This may be interpreted by the fact that the skeleton mineralization in cows of the subgroup II/1 did not reach the level of the control group.

The percentage of the ash/g of FFDM value was found to be almost identical with that of FFDM $/ \mathrm{cm}^{3}$ (Tab. 4). From the actual expression of both these parameters it follows that the decrease in relative value of $F F D M / \mathrm{cm}^{3}$ was caused almost exclusively by the decrease in minera] substance content. Also the observed ash value in $1 \mathrm{~cm}^{3}$ (Tab. 2 and 3 ) is in accordance with this finding. Histological examination of bioptic osteosamples revealed signs of impaired mineralization (particularly the demonstration of osteoid margins). 
Significant broadening of the $\mathrm{Ca} / \mathrm{P}$ ratio in ash reflects the situation in the saturation by these elements in animals of this subgroup. From the significant decrease of the $\mathrm{Ca}$ values and highly significant decrease in the $P$ values in $1 \mathrm{~g}$ of FFDM and in $1 \mathrm{~cm}^{3}$, and also from the significant broadening of the $\mathrm{Ca} / \mathrm{P}$ index, it follows that the decrease of $\mathrm{P}$ in ash was relatively more pronounced.

The values found in the subgroup II/1 are corroborated by the results of $\mathrm{V} \mathrm{r} \mathrm{z} \mathrm{g} \mathrm{u} \mathrm{l} \mathrm{a} \mathrm{(1970)} \mathrm{according} \mathrm{to} \mathrm{which}$ the skeleton mineralization could cease when the concentration of $\mathrm{P}$ becomes low. This should not, however, mean that the mineralization degree is determined by the $P$ availability only. Mineralization processes in skeleton are dependent on more factors out of which $\mathrm{Ca}$ and $\mathrm{P}$ are the most important. The degree of their metabolism disturbance then determines the character of changes in the bone marrow (impairment of mineralization, increased osteolysis ).

In the nutrition of cows of the subgroup II/2, the increased availability of $\mathrm{Ca}$ and decreased supply of $\mathrm{P}$ in the feed ration was characteristic.

Long-term excessive supply of $\mathrm{Ca}$ in the feed ration has not, however, shown itself by its level in the blood plasma, urine and $t$. coxae spongy tissue content (Tab. 1 and 2). Alteration in the chemical composition of the $t$. coxae spongy tissue was, however, more marked in this subgroup than in subgroup II/1. Highly significant drop was demonstrated in values of ash, $\mathrm{Ca}$ and $\mathrm{P}$ in $1 \mathrm{~g}$ of $\mathrm{FFDM}$ and in $1 \mathrm{~cm}^{3}$.

It follows from the highly significant broadening of the $\mathrm{Ca} / \mathrm{P}$ ratio and from the highly significant decrease in values of $\mathrm{Ca}$ and $\mathrm{P}$ ( Tab. 2 and 3 ) that a more evident decrease occurred in phosphorus. Apart from the disturbance of the proportion between the inorganic and organic phase of the spongy tissue (parameter - ash/g of FFDM) a higher resorption of spongy substance (parameter - ash $/ \mathrm{cm}^{3}$ ) also occurred. This interpretation is corroborated, apart from the percentage value of ash in $1 \mathrm{~g}$ of FFDM, also by the value of $\mathrm{FFDM} / \mathrm{cm}^{3}$ which amounted only to $84.71 \%$ of the average value of the control group (Tab. 4). Higher degree of demineralization was also apparent from histological findings.

Literature data on the influence of excessive $\mathrm{Ca}$ supply upon skeleton of heifers and dairy cows differ. I $11 \mathrm{l}$ e $\mathrm{k}$ 
et al. (1977) found in dairy cows an adverse effect of a slight excess of $\mathrm{Ca}$ in feed ration (while $\mathrm{P}$ met the requirements) on skeleton mineralization. On the other hand, $\mathrm{Z}$ e $\mathrm{t} \mathrm{t}$ e $\mathrm{r}$ h $01 \mathrm{~m}$ (1978) demonstrated a positive effect of an increased $\mathrm{Ca}$ availability on bone mineralization. $\mathrm{H}$ a $11 \mathrm{a} \mathrm{c}$ et al. (1970), L e g e l (1972, 1973) and $\mathrm{D} a \mathrm{~b} \times \mathrm{w} \mathrm{s} \mathrm{k}$ et al. (1973) found no effect of increased absorption or $\mathrm{Ca}$ supply on skeleton. The explanation of differences between our results and those of the above mentioned authors could be found in different methods used and material investigated.

It can be assumed that the cause of the increased osteolysis in cows of the subgroup II/2 could lie in an excessive $\mathrm{Ca}$ intake. According to $\mathrm{S} \mathrm{ch} \mathrm{m} \mathrm{i} \mathrm{t} \mathrm{et} \mathrm{al.}$ (1974, 1975) the decrease in osteoblast activity has to be taken into account when an excess of $\mathrm{Ca}$ occurs. $\mathrm{H}$ a a s et al. (1975) reported that when excessive $\mathrm{Ca}$ was continually available, secondary $\mathrm{Ca}$ deficit could also occur due to secondary excess of calcitonin. Also $R$ a $\mathrm{m}$ b e $r g$ et al. (1975, cit. F i c h $\mathrm{n}$ e $r$ 1978) support the hypothesis based on several causes, the main cause being perhaps an increased bone resorption. These authors observed that the $\mathrm{Ca}$ absorption represented $40-50 \%$ of orally taken amount. It asymptotically decreases with the increasing intake. In this way induced secondary Ca deficit causes an increased parathormone secretion and thus the stimulation of a more intensive bone resorption.

The found $P$ deficiency in feed rations contributed undoubtedly to the character of changes in the chemical composition of $t$. coxae spongiosa. According to

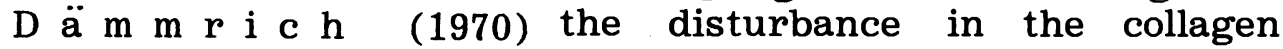
synthesis can occur due to the $P$ deficiency as was indirectly shown by the found value of ash in $1 \mathrm{~cm}^{3}$ and directly by a percentage value of the $\mathrm{FFDM} / \mathrm{cm}^{3}$ index.

The subgroup II/3 was represented by cows from one herd in which nutrition was deficient in all studied parameters. The results of the chemical analysis of $t$. coxae spongiosa (Tab. 2 and 3 ), compared with the group I, point to an unchanged ratio between the inorganic and organic portion of the spongiosa. The mineralization process of the present organic matrix was thus not impaired (ash/g of FFDM index). Highly significant decrease in the ash value in $1 \mathrm{~cm}^{3}$ of spongiosa shows, however, that resorption 
processes prevailed in the skeleton. Histological examination of biopsy samples of $t$. coxae revealed osteoporosis.

The decrease of ash content in $1 \mathrm{~cm}^{3}$ was so great that its elimination without the organic substance resorption was practically excluded. Indeed, the portion of $F F D M / \mathrm{cm}^{3}$ of spongiosa reached the value of $74.13 \%$ only (Tab. 4) compared with the controls.

In etiopathogenesis of porotic condition of the bone tissue in the subgroup II/3, the $\mathrm{Ca}$ and digestible nitrogen substances deficit in feed rations probably asserted itself in a decissive way. Deficiency of digestible nitrogen substances and particularly of $\mathrm{Ca}$ could promote the start of osteoporosis ( $\mathrm{P} \mathrm{r}$ i b t h et al. 1968; V r z g u 1 a and $B$ a r k o 1982 and others). The found deficiency of starch units in feed rations need not stay without response to the skeletal system, too, since for the formation and maturation of collagen the energy availability is important as well. From the energy and protein deficiency, osteoblastic osteoporosis can arise ( F i c h t n e r 1978, 1981).

Highly significant decrease in $\mathrm{Ca}$ and $\mathrm{P}$ values in $1 \mathrm{~g}$ of FFDM and in $1 \mathrm{~cm}^{3}$ and significantly narrowed $\mathrm{Ca} / \mathrm{P}$ ratio in ash of the subgroup II/3 demonstrate first of all the more marked lowered Ca supply in feed rations.

High actual and potential acidity of feed rations represented the definite cause of the observed condition in the subgroup II/4. Also the results of acid-base examination of blood correspond to this finding. The increased urine $\mathrm{Ca}$ and inorg. $\mathrm{P}$ excretion demonstrates this characteristics of feed rations as well.

The results of the examination of $t$. coxae spongiosa in the subgroup II/4 (Tab. 2 and 3 ) show the metabolic disturbance of the bone tissue of these cows. As a result of acidosis, a disturbance in the proportion between the bone mineral and organic portion (acidogenic demineralization) occurred - the ash percentage in $1 \mathrm{~g}$ of FFDM was $90.66 \%$ compared with the group I (Tab. 4).

As indicated by our data and statistically treated $\mathrm{Ca}$ and $P$ values and their mutial ratio (Tab. 2 and 3 ) that phosphorus participated relatively more in the decrease of ash weight. In animals of the subgroup II/4 the resorption also increased which is demonstrated by highly 
significant decrease in the ash value in $1 \mathrm{~cm}^{3}$ and by a percentage value of $\mathrm{FFDM} / \mathrm{cm}^{3}$ (Tab. 2, 3 and 4). Also the histological picture corresponded to the chemical analysis.

The result of the spongiosa sample examination in the subgroup II/4 corresponds with the examination carried out by $\mathrm{L}$ a c h m a n and $\mathrm{S}$ i e g 1 (1973), $\mathrm{S}$ i e g l (1974), $\mathrm{P} r \mathrm{i}$ b $\mathrm{t} \mathrm{h}$ (1976) and $\mathrm{K} \circ \mathrm{s} \mathrm{s}$ o w and $\mathrm{F} i \mathrm{c} \mathrm{h} \mathrm{t}$ e $\mathrm{r}$ (1977) which revealed the stimulation of osteolytic processes when acidosis was present.

For the whole group II a negative result of the aimed clinical examination is characteristic; the results of blood, blood plasma and urine analyses are also, with the exception of acid-base examination of blood and $\mathrm{Ca}$ and inorganic $P$ concentration in urine in the subgroup II/4, within the limits of reference values ( $\mathrm{J}$ a $\mathrm{g} \circ$ s et al. 1975a, 1981a).

Besides the deficiencies in nutrition, the decrease in performance and the occurrence of clinical cases of diseases of skeletal system were observed in animals.

Chemical analysis of $t$. coxae spongiosa revealed significantly or even highly significantly lowered values of followed parameters (ash, $\mathrm{Ca}$ and $\mathrm{P}$ ) compared with the control group. The values of ash are also found below the values presented as marginal ones from the viewpoint of the evaluation of physiological and pathological course of bone metabolism, the exception being the ash value in $1 \mathrm{~g}$ of FFDM in the subgroup II/3 and the ash value in $1 \mathrm{~cm}^{3}$ in the subgroup II/1 ( $\mathrm{P}$ i b o t h et al., 1972, $\mathrm{P} r \mathrm{i} \mathrm{b}$ o $\mathrm{t} \mathrm{h}$ 1976, $\mathrm{J}$ a $\mathrm{g}$ o s $\mathrm{et}$ al. 1978, 1981a). When compared with the value of $600 \mathrm{mg} \cdot \mathrm{g}^{-1}$, found by $\circlearrowright$ e $r \mathrm{n} \dot{y}$ $(1977,1980)$ as the value limiting physiological mineralization it is necessary to take into account that this value was determined on the basis of histological examination of bioptic osteosamples of dairy cows sufferring from subclinical form of metabolic osteopathy when the ash values are lower; even when the values of this parameter are lowered the histological findings may be negative.

The tendency in the ash value variation in $1 \mathrm{~g}$ of FFDM and in $1 \mathrm{~cm}^{3}$ in individual groups corresponds with the results of similar examinations carried out by $P$ r i b o t $h$ et al. (1969), $\mathrm{S}$ e f $\mathrm{f} \mathrm{n} \mathrm{r}$ and $\mathrm{P} \mathrm{r}$ i b o t h (1969), W $u j a n z$ and $L a c h m$ a $n$ (1972), S e f f $n$ e $r$ and $\quad W u j a n z$ (1973), $\quad P r i b o t h \cdot(1976,1978)$, $\mathrm{K} \circ \mathrm{n} \mathrm{i}$ (1979), $\mathrm{P} \mathrm{r} \mathrm{i}$ b $\mathrm{th}$ and $\mathrm{K} \circ \mathrm{n} \mathrm{i} \mathrm{(1980)} \mathrm{and}$ J. a g o š et al. (1981b). 
Histological examination of bioptic osteosamples demonstrated characteristic changes in assessed morphological structures.

Based on the evaluation of the results of clinico-biochemical and histological examination of bioptic osteosamples of the group II cows the disturbance in health condition of these animals could be characterized as subclinical form of metabolic osteopathy. In cows of the subgroup II/1 the changes in the bone tissue were assessed to be malacic (subclinical osteomalacia), in cows of the subgroup II/2 and II/4 as malaco-porous (subclinical mixed osteopathy - osteomalacia/osteoporosis) and in cows of the subgroup II/3 as porous (subclinical osteoporosis).

Group III included cows with the clinical syndrome of the skeletal system disease. Although the clinical finding was substantially identical in both subgroups chemical and histological examination of $t$. coxae biopsy samples gave different results in both subgroups III/1 and III/2.

Results of the blood, blood plasma and urine examination (Tab. 1) revealed only mild hypocalcemia in the subgroup III/2, other investigated parameters being within the limits of reference values ( $\mathrm{J} \mathrm{a} \mathrm{g} \circ \check{\mathrm{s}}$ et al. 1975a, 1981a).

The values of bone ash (Tab. 2) remained deeply below the limit values given by $\mathrm{P} \mathrm{r} \mathrm{i} \mathrm{b} \circ \mathrm{t} \mathrm{h}$ et al. (1972), $\mathrm{P} r \mathrm{i} b$ o t h $(1976,1978)$ and $\mathrm{J} \mathrm{a} \mathrm{g}$ o š et al. (1978), the only exception being the ash value in $1 \mathrm{~g}$ of FFDM in the subgroup III/ 2 .

Results of chemical analysis of $t$. coxae spongiosa in the subgroup III/1 (Tab. 2 and 3) showed not only a strongly disturbed ratio between inorganic and organic phase of the bone tissue but also a considerable decrease of minerals related to volume. Marked disturbance of skeleton mineralization and more intensive degradation of bone tissue observed in this subgroup were demonstrated also by data presented in Tab 4. These findings were also confirmed by histological examination of bioptic osteosamples. Highly significant decrease of $\mathrm{Ca}$ and $\mathrm{P}$ values in $1 \mathrm{~g}$ of FFDM and in $1 \mathrm{~cm}^{3}$ and highly significant narrow $\mathrm{Ca} / \mathrm{P}$ ratio point to a more pronounced $\mathrm{Ca}$ decrease.

The ash weights found in the subgroup III/1 correspond with the results of $\mathrm{P}$ r i b t h et al. (1969),

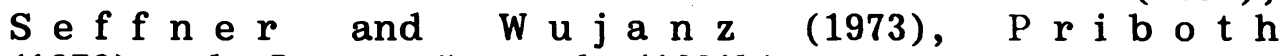
(1976) and J a $\mathrm{g}$ o $\check{s}$ et al. (1981b). 
Practically undisturbed ratio between the mineral mass and organic portion is apparent from the results of $t$. coxae spongiosa chemical analysis. The percentage of bone mineral was found to be even significantly higher than in the group I (Tab. 2, 3 and 4). Substantial decrease of minerals in a volume unit requires, however, also the loss of organic substance and thus of whole spongiosa. This presumption has also been confirmed by a low relative value of $F F D M / \mathrm{cm}^{3}$ (Tab. 4). It means, as it was also confirmed by histological findings, that the porotic process became prevalent in the spongiosa.

In accordance with the theory of $\mathrm{N}$ o $\mathbf{r} \mathrm{d}$ i $\mathrm{n}$ (1961) on the origin of osteoporosis, hypocalcemia, markedly decreased weight of bone $\mathrm{Ca}$ and highly significant narrowing of the $\mathrm{Ca} / \mathrm{P}$ ratio ( $\mathrm{Tab}, 1,2$ and 3 ) were demonstrated. From the viewpoint of etiology the found deficiency of digestible nitrogen substances and of starch units could also play a role ( $\mathrm{P} r \mathrm{i}$ b $\circ \mathrm{t} \mathrm{h}$ et al. 1968, $\mathrm{F}$ i c $\mathrm{h} t \mathrm{n}$ e $\mathrm{r}$ 1978, 1981 and others). The values of ash in $1 \mathrm{~g}$ of FFDM and in $1 \mathrm{~cm}^{3}$ in the subgroup III/2 are in accordance with the results observed by P r i b o t h $(1976,1978)$.

Based on the evaluation of the clinico-biochemical and histological examination of $t$. coxae biopsy samples the disturbance in the subgroup III/1 cows could be diagnosed as a clinical form of mixed metabolic osteopathy (osteomalacia/osteoporosis) and in cows of subgroup III/2 as clinical osteoporosis. The investigated parameters could be used for a timely objective diagnosis and differential diagnosis of osteopathies in dairy cows.

Casná diagnostika metabolických onemocnění skeletu u dojnic

V rámci prohloubení preventivní diagnostiky osteopatií $\mathrm{u}$ skotu bylo provedeno $\mathrm{v}$ průběhu zimního období komplexní sledování zdravotního stavu u $195 \mathrm{krav}$ ze 16 velkochovů a 37 klinických pacientů. Byla zkoumána diagnostická průkaznost vybraných klinickobiochemických ukazatelů pr̆i různých formách metabolických onemocnění skeletu $\mathrm{u}$ dojnic.

$\mathrm{Na}$ základě provedeného komplexního vyšetření lze konstatovat, že stanovení koncentrací Ca a anorg. P v krevní 
plazmě a moči nemá pro časnou diagnostiku metabolických onemocnění skeletu dojnic, tj. v latentním, event. prodromálním stadiu onemocnění podstatný význam. Ukazatele stanovené chemickou analýzou bioptátů $\mathrm{z}$ tuber coxae krav s různými formami osteopatií, vyvolanými nedostatky ve výživě, vykázaly charakteristické rozdíly ve srovnání s kontrolními zvíraty a byly patognomonické pro procesy probíhající ve skeletu. Toto zjištění bylo potvrzeno histologickv́m vyšetřením osteobioptátů .

Zhodnocením výsledků chemické analýzy spongiózy t. coxae byla prokázána využitelnost stanovení hmotnosti popela $\mathrm{v} 1 \mathrm{~g}$ tukuprosté sušiny, hmotnosti popela $\mathrm{v} 1 \mathrm{~cm}^{3}$ a dále indexu $\mathrm{Ca} / \mathrm{P} \mathrm{v}$ kostním popelu $\mathrm{v}$ diagnostice různých forem metabolických osteopatií u krav. Histologické vyšetření není z hlediska časné diagnostiky metabolických osteopatií krav nezbytné, lze jím však případně diagnostický závěr podpor̆it. Lze konstatovat, že stanovením hmotnosti popela $\mathrm{v} 1 \mathrm{~g}$ tukuprosté sušiny je možné již $v$ latentním, popř. prodromálním stadiu onemocnění diagnostikovat ve skeletu malatické procesy. Stanovením hmotnosti popela $\mathrm{v} 1 \mathrm{~cm}^{3}$ spongiózy procesy porotické. $\mathrm{v}$ rámci diferenciální diagnostiky lze stanovením indexu $\mathrm{Ca} / \mathrm{P} \mathrm{v}$ kostním popelu poruchu dále specifikovat.

\section{Своевременный диагноз метаболических заболеваний} скелета дойных коров

В рамках углубления профилактической диагностики остеопатий крупного рогатого скота в зимний период проводили комплексные исследования состояния здоровья 195 коров из 16 крупных коровников и 37 клинических пациентов. Устанавливали диагностическую доказательность избранных клинико-биохимических показателей при наличии разных Форм метаболических заболеваний скелета дойных коров.

На основе выполненых комплексных исследований можно сделать вывод, что определение концентраций $\mathrm{Ca}$ и неорганичческого $\mathrm{P}$ в кровяной плазме и моче не играет для постановки своевременного диагноза метаболических заболеваний скелета дойных коров, т.е. на скрытой или продормальной стадиях заболевания, существенной роли. Показатели, определенные химическим анализом биоптатов из tuber coхае ко- 
ров С разными Формами остеопатий, вызванными недостатком питания, отличались характерным расхождением по сравнению $\mathrm{C}$ контрольными животными и патогномоничностью для протекающих в скелете процессов. Данные результаты были подтверждены гистологическим исследованием остеобиопратов.

Оценкой результатов химического аналиэа спонгиоза t. coхае была установлена применимость определения массы золы в 1 г обезжиренного сухого вещества, массы золы в 1 цм $^{3}$ и индекса Са/Р в костной золе при диагнозе разных форм метаболических остеопатий коров. Гистологические исследования С точки зрения своевременной диагностики метаболических остеопатий коров не являются необходимостью, однако $\mathrm{C}$ их помощью можно подкрепить диагностические выводы. Следует отметить, что определением массы золы в 1 г обезжиренного сүхого вещества можно уже на скрытой или продормальной сталиях заболевания в скелете диагностировать болезненные процессы. Определением массы золы в 1 цм ${ }^{3}$ губчатого вещества - поротические процессы. В рамках дифФеренциальной диагностики можно более уточнить нарушение определением индекса $\mathrm{Ca} / \mathrm{P}$ в костной золе.

A c k n o w 1 e d g e me $\mathrm{n} s$

The authors are indebted to Prof. MVDr. Hugo Cerný, DrSc., Head of the Department of Anatomy, Histology and Embryology of the University of Veterinery Science, Brno who made it possible to process the histological material at the Department and gave us many valuable suggestions.

\section{References}

ČERNÝ, H.: Hodnoceni morfologické struktury $v$ kostnich bioplátech skotu vzhledem $k$ poruchám minerálniho metabolismu. Habilitation thesis, University of Veterinary Science, Brno, 1979, 137 p.

CERNÝ, H.: Funkčni morfologie chrupavky a kostni tkáně. Project report, University of Veterinary Science, Brno, 1980, $47 \mathrm{p}$.

DABROWSKI, T. - ROMANOVSKA, M. - KUCHARSKI, B. - PATYRA, W. - STANIEWSKA, R.: Badania nad zawartoscia popiolu, $\mathrm{Ca}, \mathrm{P}$ i $\mathrm{Mg}$ oraz wpływu mieszanki mineralnej MM na bilans tych składników w kościach krów. Medycyna wet., 29, 1973: 460 - 462 .

DÄMMRICH, K.: Zur formalen Pathogenese der Systemerkrankungen des Skeletts bei Tieren. Berl. Münch. tierärzt1. Wschr., 83, 1970: 106- 112. 
FICHTNER, R.: Klinisch-diagnostische Untersuchungen bei generalisie-+en Osteochondropathien von Mastbullen unter besonderer Berücksichtigung moderner Ernährungsregimes. (Dissertation A.) Humboldt-Univ. Biowiss.

Fak. - Berlin, 1978, 146 p.

FICHTNER, R.: Klinisch-diagnostische Untersuchungen bei generalisierten Osteochondropathien von Mastbullen unter besonderer Berücksichtigung moderner Ernährungsregimes. In: Beiträge der Studenten und jungen Wissenschaftler zum wissenschaftlichen Wettstreit. Tag der jungen Agrarwissenschaftler 1980. Leipzig am 9. und 10. Juni 1980. Bearb. C. Preisser. 1. Auf 1. Leipzig, Kar1-Marx-Univ., Sekt. Tierprod.VetMed., Wissenschaftsbereich Landwirtschaftliche Hoch- und Fachschulpädagogik 1981: 96 107.

HAAS, H. G. - DAMBACHER, M. A. - GUNČAGA, J.: Hypo- und Hypercalcämie als Notfall. Klin. Wschr., 53, 1975: $451-459$.

HALLAC, N. - SEIDEL, H. - SEIDEL, R.: Investigations into the mineral metabolism in Shami cows. Part. III. Preliminary studies on the use of vitamin $\mathrm{D}_{3}$ for preventing calcium and phosphorus deficiencies in dairy cows at parturition. Beitr. trop. subtrop. Landw. TropenVetMed., 8, 1970: 207 - 212 .

ILLEK, J. - JAGOŠ, P. - DOUBEK, J. - JURAJDOVÁ, J.: Dynamika změn minerální skladby kostni tkánè dojnic. Presented at: 2 . symp. o metabo1. poruchách u vysokoproduktivnych dojnic. Smolenice, June 1-2, 1977 .

JAGOŠ, P. - BOUDA, J. - ILLEK, J. - HOFfREK, B. : Rozpracováni metabolických testů $k$ určeni skrytých poruch výměny látkové $u$ dojnic $v$ podmínkách průmyslových komplexů. Project report, University of Veterinary Science, Brno, 1975a, 50 p.

JAGOŠ, P. - ILLEK, J. - BOUDA, J. - DVOŘ́K, R.: Vypracováni systému preventivni diagnostiky poruch výměny látkové $u$ skotu. Project report, University of Veterinary Science, Brno, 1981a, $39 \mathrm{p}$.

JAGOŠ, P. - ILLEK, J. - DOUBEK, J. - JURAJDOVÁ, J.: Využiti biopsie kosti $\mathrm{v}$ diagnostice subklinických osteomalácii. In: $\mathrm{Zb}$. ref. prac. sem. Veterinárna starostlivost' na úseku reprodukcie a zdravotného stavu dojníc z hl'adiska vel'kovýrobnej technológie. Trnava, January 1, 1976. Bratislava, Ústav vet. osvety 1976: 98 - 99.

JAGOŠ, P. - ILLEK, J. - DOUBEK, J. - JURAJDOVÁ, J.: Zur Diagnostik der Osteopathien bei Milchkiihen. In: Tierhyg.-Inform. 10. Eberswalde-Finow, Inst. f. angewandte Tierhyg. 1978: 129 - 137.

JAGOS, P. - ILLEK, J. - DOUBEK, J. - PROCHÁZKA, Z - KONVALINOVÁ, D. JURAJDOVÁ, J. - ČERNÅ, E. - MUSIL, V. - STEJSKAL, J. - PLÁŠEK, A.: Studium poruch metabolismu makroelementů a mikroelementů $u$ skotu $v$ podminkách velkovýrobnich technologii. Project report, University of Veterinary Science, Brno, 1981b, 104 p.

JAGOŠ, P. - ILLEK, J. - JURAJDOVÁ, J. - DOUBEK, J. - HAMŠIK, V. - STŘ́̃̌́, J. - DVOŘ́K, V. - BOUDA, J. - VALACH, Z. - POKORNÝ, L. - ČERNÁ, E. - DASKOVÁ, M. - ONDROVÁ, J. - BUREŠOVÁ, T. - PLÁSEK, A. - LOKAY, D.: Výzkum karenci minerálních látek pr̆i metabolických poruchách. Project report, University of Veterinary Science, Brno, 1975b, 175 p.

KONI, A.: Beitrag zur bioptisch-chemischen und -physikalischen Diagnostik der fütterrundsbedingten Osteopathien des Rindes unter besonderer Berücksichtigung ihrer porotisch-malazischen Mischformen. (Diplomarbeit) Kar1-Marx-Univ. Sekt. Tierprod. VetMed. Leipzig, 1979, 56 p.

LACHMANN, G. - SIEGL, W.: Experimentelle Untersuchungen zum Säure-BasenHaushalt des Rindes. Mh. VetMed., 28, 1973: 290 - 294. 
LEGEL, S.: Untersuchungen zum latenten Phosphormangel in der Entwicklung wachsender Wiederkäufer. 9. Mitt.: Das Verhalten der P- und Ca-Konzentration ausgewählter Knochen von unterschiedlich mit Phosphor versorgten graviden Färsen sowie von Nachkommen variiert mit Phosphor gefütterter Färsen. In: Jahrb. Tierernähr. Fütter. 8. Herausgegeb. W. Holzschuh - A. Hennig. Berlin, VEB Deutscher Landwirtschaftsverlag 1972/73: 199 - 207.

NORDIN, B. E. C.: The pathogenesis of osteoporosis, Lancet, 1, 1961: 1011 - 1015 .

PRIBOTH, W.: Experimentelle und klinische Untersuchungen zur Diagnostik und Frühdiagnostik der mineralmangelbedingten Osteopathien der Jungrindern. (Habil. Schrift.) Karl-Marx-Univ. VetMed. Fak. - Leipzig, 1966, $196 \mathrm{p}$.

PRIBOTH, W.: Zur Bedeutung der Knochenbiopsie als diagnostische Untersuchungsmethode beim Rind. Beschreibung des Instrumentariums und der Technik. Mh. VetMed., 22, 1967: 332 - 335.

PRIBOTH, W.: Weiterentwicklung der diagnostischen Möglichkeiten der Knochenbiopsie unter besonderer Berücksichtigung der Mengen- und Spurenelementanalyse. (F/E Aufgabe) Kar1-Marx-Univ. Sekt. Tierprod. VetMed. Leipzig, 1976, $92 \mathrm{p}$.

PRIBOTH, W.: Die derzeitigen Möglichkeiten zur Früh- und Differentialdiagnose der Osteopathien des Jungrindes und der Milchkuh. In: Tierhyg.-Inform. 10. Eberswalde-Finow, Inst. f. angewandte Tierhyg. 1978: 119 - 128.

PRIBOTH, W. - FRITZSCHE, H.: Experimentelle und klinische Untersuchungen über Störungen der Ca-P-Stoffwechselregulation bei den Osteopathien des Rindes. 1. Mitt.: Die Wirkung einer Phosphormangelfütterung auf das Skelett des Jungrindes. Chemische und physikalische Untersuchungen an post mortem entnommenem Knochenmaterial als Grundlage für die Entwicklung bioptisch-chemischer und röntgenologisch-photometrischer Verfahren. Arch. exp. VetMed., 23, 1969: 653 - 673.

PRIBOTH, W. - KONI, A.: Bedeutung einfacher Methoden für die Osteopathiediagnostik beim Rind. Mh. VetMed., 35, 1980: 380 - 384.

PRIBOTH, W. - SEFFNER, W. - WUJANZ, G.: Die Knochenbiopsie beim Rind. Möglichkeiten der chemischen und histologischen Untersuchung zur Diagnose mineralstof fmangelbedingter Osteopathien. Mh. VetMed., 23, 1968: $865-871$.

PRIBOTH, W. - WUJANZ, G. - SALIE, H. - EICHELLBERGER, P.: Bioptisch-chemische Untersuchungen zur Diagnostik und Frühdiagnostik der Osteopathien der Milchkühe. Arch. exp. VetMed., 23, 1969: 229 - 232.

PRIBOTH, W. - WUJANZ, G. - SEFFNER, W.: Zur Bedeutung und Durchführung der Knochenbiopsie beim Rind. Mh. VetMed., 27, 1972: 77 - 78.

RAMBERG, C. F., Jr. - KRONFELD, D. S. - WILSON, G. D. A.: Regulation of calcium metabolism in cattle during growth, gestation, lactation and changes in diet. In: Proc. IV Int. Symp. Ruminant Physiology. Sydney August 1974. Digestion and metabolism in the ruminant. Ed. I. W. McDonald - A. C. I. Warner. Armidale, University New England Publishing Unit 1975: 231 - 242 .

ROSSOW, N. - FICHTNER, R.: Ätiologie und Pathogenese generalisierter Osteochondropathien bei Mastrindern. Mh. VetMed., 32, 1977: 844 - 850.

SEFFNER, W. - PRIBOTH, W.: Vergleichende histologische und chemische Untersuchungen an bioptisch gewonnenen Knochengewebsproben von Rindern. Mh. VetMed., 24, 1969: 18 - 21. 
SEFFNER, W. - WUJANZ, G.: Histologische und chemische Untersuchungen an bioptisch gewonnenen Hüfthockcerspongiosaproben von Kühen in einem immissionsbeeinflussten Gebiet. Mh. VetMed., 28, 1973: 384 - 387 .

SCHMIDT, U. J. - BRUSCHKE, G. - KALBE, I. - REINHARDT, CH. - WEBER, R. - GEORGI, G. R.: Hormonelle Wirkungen auf den Knochenstoffwechsel unter besonderer Berücksichtigung der Osteoporose. 1., 2. Teil. Dtsch. Gesundh.-Wes., 29, 1974: 2449 - 2453; 30, 1975: 9 - 15.

SIEGL , W.: Experimentelle Untersuchungen zum Säure-Basen-Haushalt Rindes. (Dissertation A.) Kar1-Marx-Univ. Sekt. Tierprod. VetMed., Leipzig, 1974,200 p.

VRZGULA, L.: Choroby látkového metabolismu. In: GDOVIN, T. et all.: Vnútorné choroby hovädzieho dobytka, oviec, koz a ošipaných. 2. ed. Bratislava, Priroda 1970, pp. 463 - 533.

VRZBULA, L. - BARTKO, P.: Poruchy metabolizmu minerálnych látok. In: VRZGULA, L. et all.: Poruchy látkového metabolizmu hospodárskych zvierat a ich prevencia. 1. ed. Bratislava, Priroda, 1982, pp. 93 - 168.

WUJANZ, G. - LACHMANN, G.: Zur Problematik der Diagnose und Frühdiagnose von Stoffwechselerkrankungen der Milchkuh im System der veterinärmedizinischen Produktionskontrolle. Wiss. Z. Kar1-Marx-Univ. Lpzg, Math.-naturwiss. R., 21, 1972: 331 - 336 .

ZETTERHOLM, R.: Bone mineral changes in dairy cows. The effect of low and high calcium feeding during late pregnancy and at parturition. Acta vet. scand., 19, 1978: $30-38$. 